\title{
PDZK1 wt Allele
}

National Cancer Institute

\section{Source}

National Cancer Institute. PDZK1 wt Allele. NCI Thesaurus. Code C114323.

Human PDZK1 wild-type allele is located in the vicinity of $1 \mathrm{q} 21$ and is approximately $37 \mathrm{~kb}$ in length. This allele, which encodes $\mathrm{Na}(+) / \mathrm{H}(+)$ exchange regulatory cofactor $\mathrm{NHE}-\mathrm{RF} 3$ protein, is involved in the modulation of ion channel and signaling protein localization. Variations and aberrant expression of this gene may be associated with metabolic syndrome and drug resistance of multiple myeloma, respectively. 